\title{
Website-Based Contextual Learning Design of Han Script
}

\author{
Mulawarni ${ }^{1}$, Emzir2$^{2}$, Ratna Dewanti ${ }^{3}$ \\ mulawarni_pb17s2@mahasiswa.unj.ac.id, emzir.unj@unj.ac.id, rdewanti@unj.ac.id
}

\begin{abstract}
This study aims to produce a website-based contextual learning prototype design of han script used for training of Han script learning by using a contextual approach. Prototype Research on Contextual Learning Design of Han Script Based on Website is the answer to the problems faced by Mandarin Language teachers in SMA/SMKMA in learning Han script. By using the ADDIE model focused on the Design step based on document analysis and literature review, the 30 Han characters chosen for daily use based on the formation of the word 造字 方法 "zào zì fāngfă. Seven stages in contextual learning implied in the website prototype named hanyupedia.id. The material is designed based on the data obtained from the needs analysis results consisting of material à Hànzì qǐyuán， 汉字 à hànzì jiégò， 汉字 造字 法 hànzì zào zì fă and 汉字 书法à hànzì shūfă guīzé, which are available in the form of text, images, and videos for activity and training.
\end{abstract}

Keywords: contextual learning, han script, website

Abstrak: Penelitian ini bertujuan untuk menghasilkan prototipe rancangan pembelajaran kontekstual aksara Han berbasis website yang digunakan dalam diklat pembelajaran aksara Han dengan menggunakan pendekatan kontekstual. Penelitian Prototipe Rancangan Pembelajaran Kontekstual Aksara Han Berbasisi Website ini merupakan jawaban dari masalah yang dihadapi guru Bahasa Mandarin jenjang SMA/SMK/MA dalam pembelajaran aksara Han. Dengan menggunakan model ADDIE pada yang terfokus pada langkah Design berdasarkan analisis dokumen dan kajian literatur maka dipilih 30 buah aksara Han yang digunakan dalam keseharian berdasarkan pada pembentukan kata 造字方法” zào zi fāngfă. Tujuh tahapan dalam pembelajaran kontekstual tersirat dalam prototipe website yang diberi nama hanyupedia.id. Materi dirancang berdasar pada data yang didapatkan dari hasil analisis kebutuhan terdiri dari materi汉字起源Hànzi qǐyuán, 汉字结构hànzi jiégòu，汉字造字法hànzì zào zì fă dan 汉字书法规则 hànzì shūfă guīzé, yang tersedia dalam bentuk teks, gambar dan video, aktifitas dan latihan.

Kata Kunci: $\quad$ pembelajaran kontekstual, aksasara han, website

\begin{tabular}{|l|l|l|l|}
\hline Submitted: June 2020 & Reviewed: July 2020 & Accepted: August 2020 & Published: September 2020 \\
\hline
\end{tabular}

\footnotetext{
1 Universitas Negeri Jakarta

2 Universitas Negeri Jakarta

3 Universitas Negeri Jakarta
} 


\section{INTRODUCTION}

earning foreign languages, especially Mandarin, is not something easy, it takes an interest and "passion" of the learner. In learning Mandarin, it is not much different from other foreign languages

including: listening, speaking, reading and writing. Han script or Hanzi 汉字 is a Chinese writing system that is used as a means of written communication and is still used today (Sun, Liu, Hu, \& Liang, 2014).

Han script is a drawing-shaped streak that is famous for the visual complexity of its characters (Liu, Chuk, Yeh, \& Hsiao, 2016). Each Han script consists of a combination of several strokes that can form 200 different basic stroke patterns. The pattern is the smallest functional unit that has sound and meaning. Therefore writing Han characters cannot be considered trivial because many students make writing errors (Hsiao, Chang, Chen, Wu, \& Lin, 2015). Writing errors that are not according to the standards made by students and teachers become the party responsible for providing guidance on how to write the right script (Misbakhudin, 2013).

Stroke writing errors also occur because many of the learners are less proficient in the script configuration. In addition, teachers are also less proficient and do not master the Han script configuration method (Wen, 2017), physical form errors in writing include lack of strokes, excess strokes, writing errors due to different forms of strokes, and misplaced strokes (Supriadi \& Soedirman, 2018), with the lack of mastery of basic strokes along with the way of writing, so the writing produced does not meet the standards, students will have difficulty if the stroke has more than 10 strokes. Students have difficulty recognizing characters that have similarities (Tin et al., 2018). While the difficulty faced by teachers in teaching Mandarin is that teachers lack basic knowledge of language. Among them is one of the origins of the Han characters or early Han characters, their development, the structure of the Han characters, the components of the Han characters, the relationship between characters and sounds, the order of writing, the way they were written, and the way they were taught. (Zhengyu, 2018).

How to learn Han characters in general is by writing Han characters many times. Another way is to tell the origin of the Han script formed which was found to be able to accelerate and facilitate learners remembering the Han script (Retnoningsih, Haswanto, \& Ihsan, 2015). Writing especially writing Han characters is included in indirect communication which occupies the highest level. Writing is a productive and expressive skill. However, before being able to arrange the Han characters into sentences and essays, the teaching of Han characters became a basic skill (Agita Kurnia Sari, 2011).

learning Han based website, is felt by researchers to be the right choice at this time. This is because it can facilitate the Mandarin language teacher to learn. The use of websites in learning can combine multimedia elements (animation, video, audio, graphics) so as to make learning more interesting and can add to the learning experience. this can also be due to being more focused, structured, and can deepen a better understanding of the subject (Tambunan, 2016). Web Based Learning For Teaching has proven to make it easier for teachers to transfer material taught to students. this is because the material is easily accessible. Besides web-based learning makes students become active in understanding the material, this is because the material can be accessed anytime and anywhere. (Divayana, Suyasa, \& Sugihartini, 2016).

Based on the explanation above, the formulation of the problem in this article is how to design a contextual learning model for Han script based on the hanyupedia.id website. This research will create a contextual learning design for website-based Han script which is named hanyupedia.id. Website learning design is made according to the seven stages of contextual learning. 
The Chinese character, known as the Han Script (汉字 hànzi), is a written language used as a communication tool for thousands of years of the Chinese people. According to Han Jiantang in the book 《中国文化》“汉字是记录汉语的文字。汉字对发展中华民族的优秀文化起了重大作用 。汉字是世界最古老的文字之一”。Han Script 汉字is a written language recording system. The Han script plays a very important role in developing Chinese culture. Han script is one of the oldest writing systems in the world that contains a lot of information and cultural ideology that is much earlier or more than historical records (Tang, 2017). To be able to read the characters, Han Zhou Youguang (Father of Pinyin) who made a system of romanizing Han characters, there is a method of reading Han characters with this romanization known as 拼音 (Pīnyīn). This was made to make it easier for foreign students to read the Han script.

Yang yangtu in his book 1000 Chinese Classics (Retnoningsih et al., 2015) wrote the Chinese philologist Xu Shen, he did an analysis of Han characters which then divided them into 6 (six) categories according to their forming structures known as 六 书 liù shū. This consists of (1) pictorial pictorial characters (象形 xiàngxíng) which refer to icons (forms), ideas, and meanings. The Han script refers to icons such as the script 山 shān which means mountain. (2) ideographic characters (指 事 zhì shi) like 拿 ná which means to take. This character, if the component components are separated, you will see the smallest component consisting of the components " rén 'person / human' , 口 kǒu 'mouth' , and 手 shǒu 'hand', activities using the hands, (3) the picto-phonetic character (形 声 xíngshēng), the Han character consisting of meaning is marked by sound, for example: 江 Jiāng (river), the 江 character consists of ( $;$ shui) is a water symbol that functions as a sign of meaning and ( $I$ gōng) as a symbol of sound. (4) the combined script of meaning (会意 huiy ak) the character whose formation is meaning such as: 木 (mù tree / wood, while 林 (lín forest) consists of 2 trees. (5) the loan character meaning （假借 jiăjiè） for example, like the character 我 (W, I), so it is actually a weapon, but to borrow the meaning from 自 (Zì yourself). (6) the phonetic transfer script. （专注 zhuānzhù.

Contextual learning or commonly known as CTL (Contextual Teaching Learning) is a system that is able to stimulate the work of the brain to arrange patterns to realize meaning (Johnson, 2014). Furthermore, Priansa wrote that CTL learning is a learning concept that links material with real-life facts. This learning emphasizes the planned learning activities that have been designed by the teacher (Priansa, 2017).

In the CTL learning model, Sanjaya states that there are 5 (five) important elements that need attention, namely: activating knowledge that has been previously owned; acquisition of knowledge (aquiring knowledge) by studying the whole and then pay attention to details; understanding knowledge (understanding knowledge) through the formulation of hypotheses, exchange opinions with others to obtain validation and revision of their development and experience; apply knowledge (experience knowledge) experience in the latest situation; reflecting the strategy of developing knowledge (reflencting knowledge) (Sanjaya, 2013). In addition to the 5 (five) elements of CTL, Sanjaya also explained that CTL has seven main components as its main characteristics, namely: (1) Construction (Constructivism), which is the basis of thinking, which argues that in addition to concepts and rules to be desired, but also able to build knowledge of these concepts and rules. (2) Finding (Inquiry), learning activities are directed to find knowledge based on the knowledge they already have. (3) Questioning (questioning), knowledge possessed by someone begins with asking, so that in the CTL implementation information is extracted through questions given by the teacher. (4) Learning Community, which is meant by the learning community is the ability to cooperate between students. (5) Modeling (modeling), in a learning teacher has a role as a model that can inspire students. (6) Reflection (reflection), in this activity the teacher helps 
students to connect what has been learned with their experiences, so that later students know what to do if they experience something similar. (7) Authentic Assessment is done by collecting students' information related to what they have done by testing their skills and knowledge.

The contextual learning of Han characters is done by introducing basic characters while explaining the structure of characters that can be related to daily life. Han characters in contextual learning are chosen from several characters that are often used and can be associated with reality, such as: 美 mèi (beautiful / beautiful / beautiful), these Han characters consist of 2 combined characters 羊 yáng and 大 dà. Chinese culture believes that a big, strong sheep / goat is symbolized as perfection, as well as beautiful women are considered a symbol of perfection. The Han script and culture in contextual learning can be described as follows:

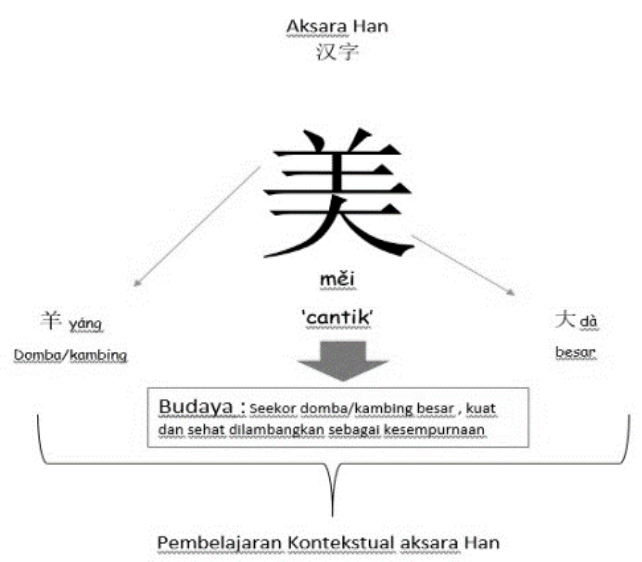

Picture 1. Cultural Relationship with the Han script in the contextual learning of han script

This website-based learning is where participants and instructors can interact supported by video call facilities. Moreover, learning activities become fun because the material is presented not only with pdf files but also uses pictures, videos, for evaluating students' assessment given assignments and quizzes. While instructors can do monitoring, tracking, collaboration to find out the learning outcomes of students (Evi, Sulthoni, \& Arafah, 2015). Learning that utilizes the web as a hypermedia teaching program is intended to create a conducive learning atmosphere. Utilization of the web as a model of distance learning or e-learning is divided into two namely synchronous and asynchronous. Synchronous is the interaction between students and teachers through the web happening at the same time (virtual) and asynchronous is the interaction between students and teachers does not occur directly, this means that students can learn at any time without having to interact directly with the teacher. Learning through the web may look easy, but in designing it takes seriousness to the implementation stage. Besides needing an internet network, this learning requires a special instructor model. This instructor model is a vital part and should receive special attention as a determinant of the effectiveness of the learning process between teachers, students, material and other supporting parties (Rusman, 2012:295).

\section{RESEARCH METHODS}

This research is a type of Research and Development (R\&D) research, Research and Development is a research method used to produce products and test these products (Sugiyono, 2008). The development model used in this study is the ADDIE model, this research had a limitation that only finished in at the Design stage.

To design website-based learning, this will be used literature review and document analysis in accordance with the needs analysis that has been done before. The Han characters chosen are 30 characters that are used in daily life based on word formation “造字方法” zào zì fāngfă its consisting of 象形xiàngxíng, 指事zhì shì, 会意 huìyì, dan形声xíngshēng. The 30 Han characters consist of 
人、口、山、火、日、月、大、马、妈、手、上、下、中、好、男、安、休、明、国 、早、看、美、努、哭、见、看、休、林.

\section{RESULTS AND DISCUSSION}

In this study, the design of the web-based Han contextual learning model was designed using 7 main components in CTL.

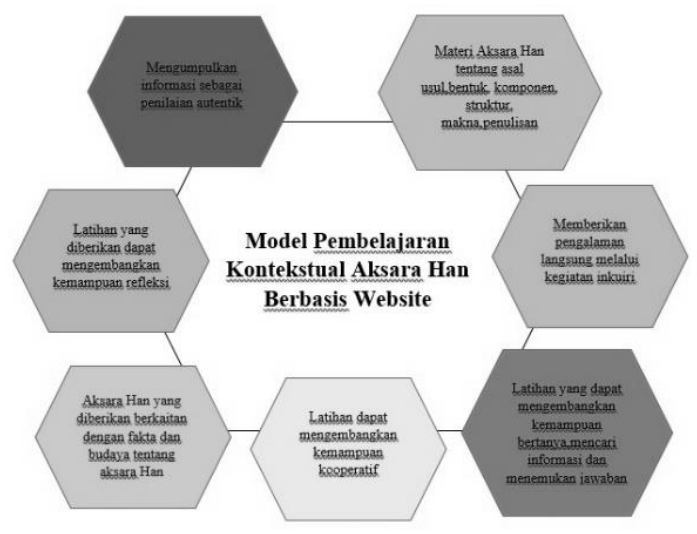

Picture 2. Website-based Han Script Learning Model Design

The design of the contextual learning model of Han script based on the website in the picture above is explained in the syntax as follows:

The Constructivism Phase assumes that the knowledge learned is the result of constructing knowledge based on experience through interaction (Herrera Díaz \& González Miy, 2017). At this stage learning focuses on the knowledge of the origin of the Han script and its development, so that the learner (Mandarin teacher) who learns the Han script material in the training can construct the knowledge possessed with the knowledge received, as well as relevant to the real world context. The purpose of this phase is to link Chinese culture with the development of the Han script which can motivate teachers to connect knowledge with reality and how to teach it back to their students. With construction, teachers can build new skills to teach Han characters efficiently (Afiani, 2018). This phase provides material on the origin of the Han script, the formation of the Han script, the sound of the script, the meaning, components, structure and rules of writing the Han script and Chinese culture related to the Han script, as shown below:

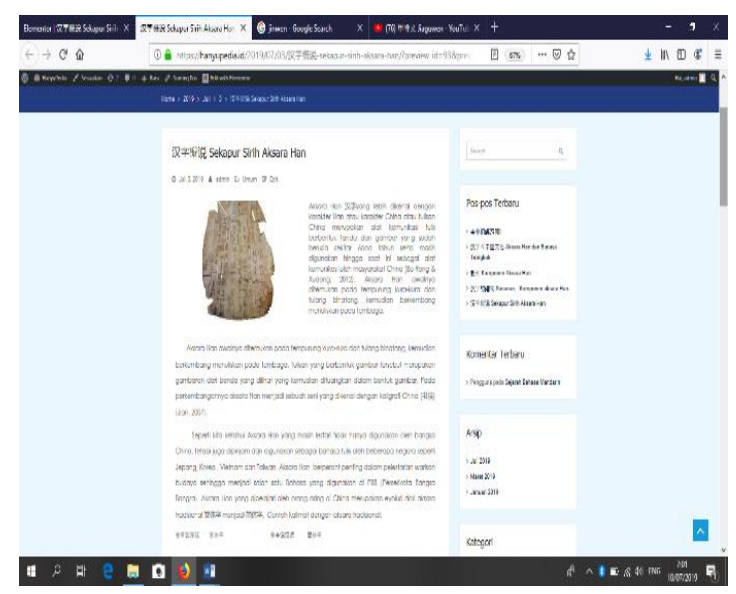

Picture 3. Constructivism Stage on the website https://hanyupedia.id 
Inquiry Phase

This stage of inquiry is the stage at the core of contextual learning. This is where the experience provided by the learner can find for themselves the information needed to solve problems and achieve learning success (Wahyuni \& Arisa, 2018). In this design the researcher presents the experience by giving a picture that reads“美丽的心情 měili de xīnqíng” which means very good mood. Then the students are asked to analyze the character "美" , how the evolution of the script, the cultural information behind the script and how to write it. 美 měi is a combined script consisting of characters 羊 yáng "sheep / goat" and 大dà "big". Based on the information obtained, the relationship between sheep I goats and large is, according to Chinese culture, sheep are a symbol of prosperity while large sheep are the perfect thing. This phase provides direct experience through inquiry activities, analyzing the form of Han characters contained in a sentence, picture and sign.

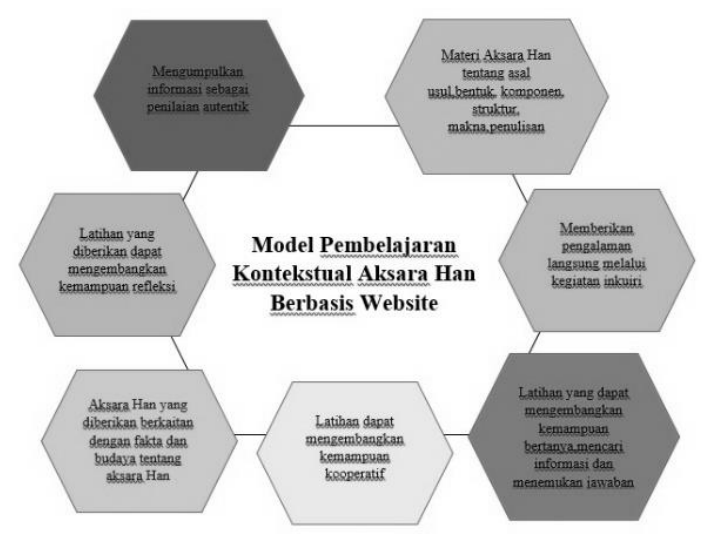

Picture 4. Inquiry Phase on the website https://hanyupiedia.id

Questioning

This phase provides exercises that can develop the ability to ask questions when things are not understood. This is to find information and find answers based on knowledge and information obtained. This questioning stage is the stage that arouses the curiosity of the learner, the questioning activity can be done with think-pair-share. First will be given a pictorial sentence that describes a man and then read" 一个男人最重要的应该是坚强” yīgè nánrén zuì zhòngyào de yīnggāi shì jiānqiáng that had meanings was 'The most important thing for a man is to be strong'. 男 nán script is given a different color, participants will ask why the 男 character is given a different color. Then the teacher will ask participants to explain about the cultural information that is behind the character, the structure, the components of the script and how to write the script based on the previous inkuri stage.

At this stage students are given the opportunity to think and find answers privately which are then shared with other friends. Questioning can also motivate students to be active in learning activities (Sunarto, Sumarni, \& Suci, 2008) as well as to improve the ability to think critically about the problems faced (Kusumah, Sabandar, \& Herman, 2016). 


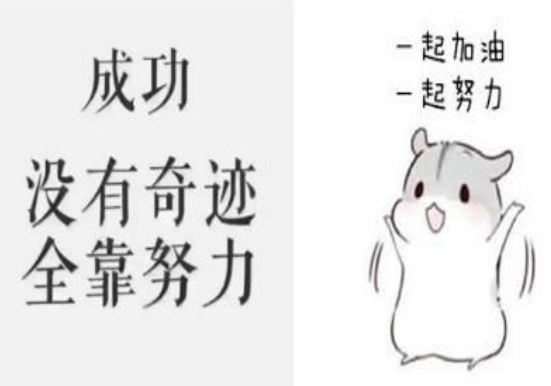

Gambar 5. Stage questioning on the website https://hanyupedia.id

Learning Community

This phase is to do exercises that can develop the ability to work together and independently. In this section this section is the same as the inkuri and questioning section. Students will learn through interaction with peers in the training by discussing the themes that will be given by the teacher. Contextual learning encourages fellow learners to learn from each other by discussing in the "chat rooms" provided in hanyupedia.id (Santoso, 2017).

\section{Modelling}

Forward, giving activities by modeling the Han script (努力) which is then analyzed about its components, structure, sound, meaning and cultural elements contained in the script. In this section, the teacher or students can give examples of illustrated sentences as a form of modeling. Choose the script to be analyzed and then share the information. Starting from cultural information, components, how to write to how the characters are easy to remember. For example:

Participants can analyze Han 加油 or 努力 or perhaps others, then explain the results of the theme as modeling (Sihono, 2004)

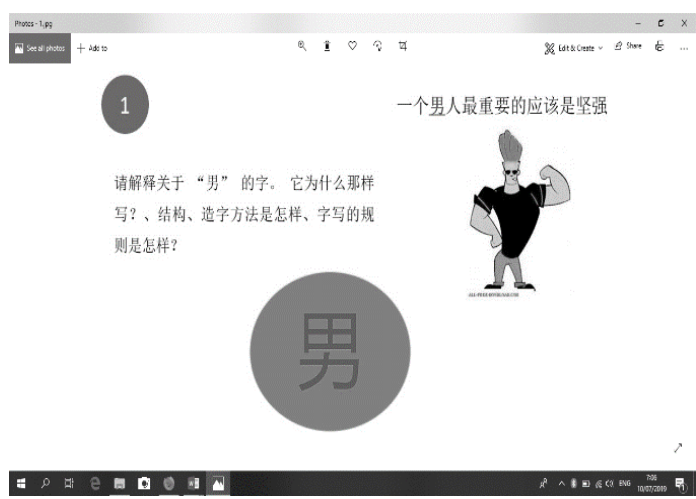

Gambar 6. Modeling stage in the website https://hanyupedia.id

This phase provides activities that can help participants to relate what they have learned with experience based on the examples provided (practicing reflection skills). Still in (Sihono, 2004), This phase provides activities that can help participants to relate what they have learned with experience based on the examples provided (practicing reflection skills). Still in (Sihono, 2004), reflection is an important part of contextual learning. With reflection, students can find out what has been learned and 
new knowledge obtained or knowledge that is reminded. Then contemplating it turns out Han characters can be learned with a contextual learning model.

\section{Authentic Assessment}

Authentic assessment according to Mueller (Mueller, 2008) Authentic assessment according to Mueller is an assessment that asks students to show the work that has been done then apply what is obtained from the knowledge and skills. While O'Malley and Pierce in \{Formatting Citation\} explained, that authentic assessment involves all forms of performance measurement that reflect relevant motivations, attitudes, achievements, and learning in learning activities. In this section, examine participants with exercises and activities that serve to gather information and test their skills and knowledge for the Han script material. This is also to find out whether the participants have been able to apply the knowledge that has been obtained or not.

\section{CONLUSIONS AND RECOMMENDATIONS}

Han 汉字 is a written language recording system. Han script plays a very important role in developing Chinese culture. The contextual learning of Han characters is done by introducing basic characters while explaining the structure of characters that can be related to daily life. Han characters in contextual learning are chosen from several characters that are often used and can be linked to reality.

This website-based Han script contextual learning design was made for Mandarin language teachers with reference to the 7 stages of contestual learning (constructive, inquiry, asking, community learning, modeling, reflection and authentic assessment). This emphasizes the ability of participants to be able to express the knowledge gained. It can also be used as a model for learning Han characters for students. Contextual learning of Han characters integrates Chinese culture and circumstances, so students can easily remember Han characters and how to write in accordance with the rules of writing.

The learning design using the hanyupedia.id website as a learning medium is expected to help Mandarin teachers to be able to learn and develop their competencies..

\section{REFERENCE}

Afiani, A. (2018). Pembelajaran kontekstual kon (cotextual. Al Muta'aliyah STAI Darul Kamal NW Kembang Kerang, I(3), 80-88. Retrieved from http://ejournal.kopertais4.or.id/sasambo/index.php/mutaaliyah/article/view/3005/2208

Agita Kurnia Sari, L. (2011). Pengajaran Menulis Hanzi di Kelas X. Retrieved from https://eprints.uns.ac.id

Divayana, D. G. H., Suyasa, P. W. A., \& Sugihartini, N. (2016). Pengembangan Media Pembelajaran Berbasis Web Untuk Matakuliah Kurikulum dan Pengajaran di Jurusan Pendidikan Teknik Informatika Universitas Pendidikan Ganesha. Pendidikan Teknik Informatika (JANAPATI), 5(3), 149-157. Retrieved from https://ejournal.undiksha.ac.id/index.php/janapati/article/view/9922

Ermawati, Siti., \& Hidayat, T. (2017). Penilaian autentik dan relevansinya dengan kualitas hasil pembelajaran (persepsi dosen dan mahasiswa ikip pgri bojonegoro). Jurnal Pendidikan Ilmu Sosial, 27(1), 92-103.

Evi, A. N., Sulthoni, \& Arafah, H. (2015). Pengembangan Media Pembelajaran Online Berbasis Web Pada Mata Kuliah Dadar-Dasar Kepenyiaran Di Jurusan Teknologi Pendidikan Universitas Negeri Malang. Retrieved from http://karya-ilmiah.um.ac.id/index.php/TEP/article/view/27643

Herrera Díaz, L. E., \& González Miy, D. (2017). Developing the Oral Skill in Online English Courses Framed by the Community of Inquiry. PROFILE Issues in Teachers' Professional Development, 19(1), 73. https://doi.org/10.15446/profile.v19n1.55957 
Hsiao, H. S., Chang, C. S., Chen, C. J., Wu, C. H., \& Lin, C. Y. (2015). The Influence of Chinese Character Handwriting Diagnosis and Remedial Instruction System on Learners of Chinese as a Foreign Language. Computer Assisted Language Learning, 28(4), 306-324. https://doi.org/10.1080/09588221.2013.818562

Johnson, E. B. (2014). Contextual Teaching and Learning (New Editio). Kaifa.

Kusumah, Y. S., Sabandar, J., \& Herman, T. (2016). Mathematical Critical Thingking Ability Through. IndoMS-JMS, 6(1), 53-62. Retrieved from https://files.eric.ed.gov/fulltext/EJ1079602.pdf

Liu, T., Chuk, T. Y., Yeh, S. L., \& Hsiao, J. H. (2016). Transfer of Perceptual Expertise: The Case of Simplified and Traditional Chinese Character Recognition. Cognitive Science, 40(8), 1941-1968. https://doi.org/10.1111/cogs.12307

Misbakhudin, A. (2013). Universitas Negeri Surabaya. Jurnal Pendidikan Tata Niaga, 1(April). https://doi.org/10.1074/jbc.271.41.25173

Mueller, J. (2008). Authentic Assessment Toolbox. North Central Collegehttp.

Priansa, D. J. (2017). Pengembangan Strategi \& Model Pembelajaran Inovatif, Kreatif dan Prestatif Dalam Memahami Peserta Didik. Bandung: Pustaka Setia.

Retnoningsih, S., Haswanto, N., \& Ihsan, M. (2015). Visualisasi Tulisan 14 Hanzi Dasar Berupa Piktograf Sebagai Metode Belajar Mudah Mengenal Aksara China. 3(3), 43-54. Retrieved from http://lib.itenas.ac.id/kti/wp-content/uploads/2017/05/Visualisasi-Tulisan-14-Hanzi-Dasar-BerupaPiktograf-Sebagai-Metode-Belajar-Mudah-Mengenal-Aksara-China.pdf

Rusman. (2012). Belajar dan Pembelajaran Berbasis Komputer. Bandung: Alfabeta.

Sanjaya, W. (2013). Strategi Pembelajaran Berorientasi Standar Proses Pendidikan (10th ed.). Jakarta: Kencana.

Santoso, E. (2017). Penggunan Model Pembelajaran Kontekstual Untuk Meningkatkan Kemampuan Pemahaman Matematika Siswa Sekolah Dasar (Studi pada siswa kelas V SDN Sukarasa II Kecamatan Samarang Kabupaten Garut Tahun pelajaran 2014-2015 ). Jurnal Cakrawala Pendas, 3(1), 16-29. Retrieved from jurnal.unma.ac.id/index.php/CP/article/download/407/388\%0A\%0A

Sihono, T. (2004). Contextual Teaching and Learning (CTL). Jurnal Ekonomi \& Pendidikan, 1(1), 63-64. https://doi.org/10.1145/1028664.1028744

Sugiyono. (2008). Metode penelitian pendidikan:(pendekatan kuantitatif, kualitatif dan R \& D). Alfabeta.

Sun, L., Liu, M., Hu, J., \& Liang, X. (2014). A Chinese character teaching system using structure theory and morphing technology. PLOS ONE, 9(6), 1-11. https://doi.org/10.1371/journal.pone.0100987

Sunarto, W., Sumarni, W., \& Suci, E. (2008). Hasil Belajar Kimia Siswa dengan Model Pembelajaran Metode Think-Pair-Share dan Metode Ekspositori. Jurnal Inovasi Pendidikan Kimia, 2(1), 244-249. https://doi.org/246 Jurnal Inovasi Pendidikan Kimia, Vol. 2, No. 1, 2008, hlm 244-249

Supriadi, N., \& Soedirman, U. J. (2018). Analisis Kesalahan Penulisan Huruf Hanzi Bahasa Mandarin Oleh Pembelajar Pemula di Purwokerto. Jurnal IImiah Lingua Idea, 9(1), 1-7.

Tambunan, H. (2016). Pengembangan pembelajaran berbasis WEBSITE Dalam Mata Kuliah Pengaturan Mesin Listrik. (1), 321-332. $\quad$ Retrieved from https://journal.uny.ac.id/index.php/cp/article/view/1260/pdf

Tang, J. (2017). On the Philosophical Construction of Discourse Field of Chinese Character. Open Journal of Social Sciences, 05(04), 260-269. https://doi.org/10.4236/jss.2017.54023 
Tin, T. G., Atan, N. A., Mohamad Said, M. N. H., Ali, M. F., Mohd, S., \& Abd Hamid, M. Z. (2018). Integrating Animations in Chinese Character Writing Based on Cognitive Theory of Multimedia Learning to Promote Students' Writing Skills. International Journal of Interactive Mobile Technologies (IJIM), 12(7), 97. https://doi.org/10.3991/ijim.v12i7.9671

Wahyuni, S., \& Arisa. (2018). Efektifitas Model Pembelajaran Inquiry Based Learning Dalam Meningkatkan Pembelajaran Bahasa Indonesia Siswa SMP Kecamatan Sabbangparu. Jurnal KIBASP (Kajian Bahasa, Sastra Dan Pengajaran), 1(2), 212-222. https://doi.org/https://doi.org/10.31539/kibasp.v1i2.225

Wen, R. (2017). 构形法在对外汉字初期教学中的应用. 语言文字学术研究, 17(187), 19-21. https://doi.org/10.14014/j.cnki.cn11-2597/g2.2017.17.006

Zhengyu, S. (2018). 关于对外汉字教学一些问题的思考. 汉字教学综论, 3(3), 3-19. Retrieved from

http://gb.oversea.cnki.net/KCMS/detail/detail.aspx?filename=GZZY201803002\&dbcode=CJFD\&db name=CJFDTEMP 